مجلة كلية الخدمة الاجتماعية للار اسات والبحوث الاجتماعية - جامعة الكيرم

\title{
Social Work Education and Contemporary Social Transforms in Egypt
}

Emad M. Abd El Salam

Associate Professor Department of Social Work fields

Fayoum University- Faculty of Social work
Samar S. Sofy

Ph.D. In Social work

Department of social development \& planning 
مجلة كلية الخدمة الاجتماعية للدر اسات و البحوث الاجتماعية ـ جامعة الكيوم 
Abstract:

Our world is undergoing unprecedented disruption across health, social, and economic systems, which was shaped by sequential waves of events. So that presents significant challenges for social work education. Each social work student, teacher, and program is unique, and so have been their responses to Contemporary Social Transforms. In the present paper, Exploring and understanding Contemporary Social Transforms in Egypt, and Exploring and analyzing reality of Social work education in the Developing country during Contemporary Social Transforms especially in Egypt.

Keywords: social work education, Contemporary Social Transforms, social justice, international social work, refugees.

\section{Introduction:}

The consequences of social transforms in Egypt caused special and varied needs that are new challenge. That challenges require modernizing methods and strategies of social work education, and updating for its curriculums to treat with new waves of social problems which have emerged and become part of the challenges currently many countries are facing it, such as unaware using of social media create new social problems, political instability, Wars, corruption, poverty, and The novel COVID-19 pandemic.

In other side an awareness of social work practice and education is increased predominately because the main Task of Social Work is likely to be the improvement of citizen life quality, that in general, and weak people in particular, in other side its concern will be in both of broad fields of social planning, and in community development, the current paper will discuss how that happened. (Osei-Hwedie, Ntseane, \& Jacques, 2006, p. 25)

So, it's important to equip social workers with understanding Transforms in their region and its social, economic consequences, also they must be realized the main issues in their field, social forces in it, and the current problems of their community to be able find suitable method through which progress can be achieved on a wide front.

\section{Literature review}


The main target of social worker work is placing welfare systems under great strain which is affected by population ageing, economic circumstances and human behavior. In England, the social work profession extensively was reformed. Frist important section in social work education is Training curricula, so they started their redesign process with them in the context of new standards of competence for social workers - which are called the Professional Capabilities Framework (PCF). That process aimed to achieve one main objective which is equipping students with qualifying to address an extensive range of human problems through social work knowledge baseinstrumental, interpretive and emancipatory.

Social work is humanitarian profession so; the nature of it varies greatly between countries and over time, because of that it must be regenerate. For example, In Europe, there are increasing the demands on welfare services, as consequences of population ageing, maladaptive behavior, migration and economic insecurity, so major changes are taking place in social work education in England

In 2007, death of a young child triggered a highly-publicised, it caused an extensive review commissioning by the British government in 2008." Evidence submitted to the review highlighted inadequate professional training, insufficient support for on-going professional development, and poor professional leadership as features of contemporary social work in England." And it argued that the major challenges to social work which were inadequately reflected in standards of education and practice is the consequences of globalisation and the destruction of cultural norms and values presented. (Ring, 2014, p. 239)

The reform of social work curriculums in England has been a complete revision of professional standards, published in the form of a 'Professional Capabilities Framework' which is including the next domains. 


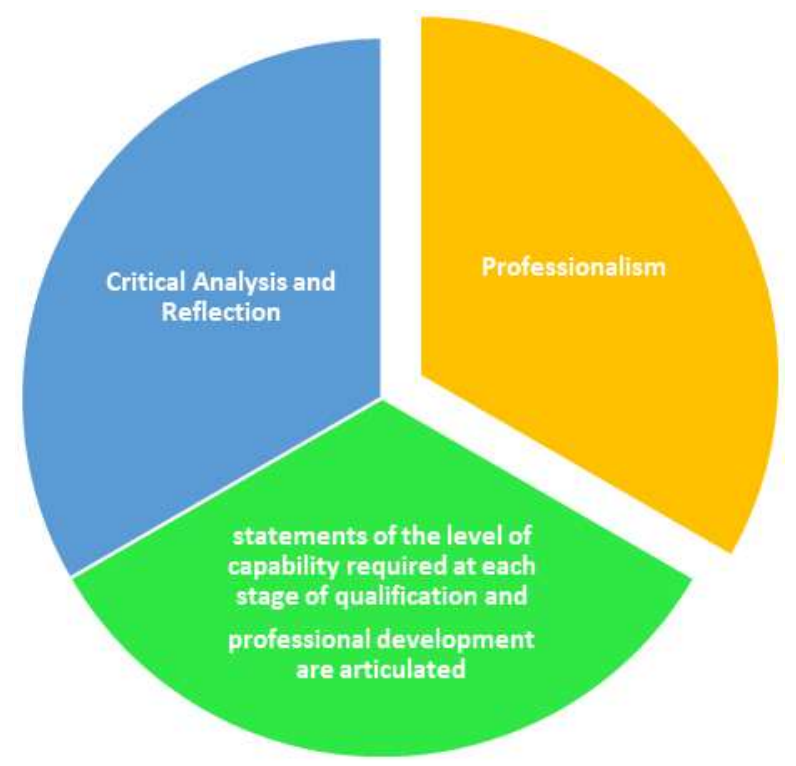

Figure 1: domains of social work Professional Capabilities Framework'

Such concerns are not restricted to Western Europe, in Arab region a speed transforms as consequences of wars, political changes, economic circumcises, social problems and challenges, even the effectiveness of technology, that require redesigning for social work curriculums there.

But in the following lines discussion of current Characteristics of Social Work Education in Arab region, then discretion of Arab region transforms types which require social workers are equipped with new awareness and qualifications.

\section{Frist: Characteristics of Social Work Education in Developing} Countries

The main Task of Social Work in developing Countries at current stage is likely to be the improvement of the quality of life for the citizens, that in general, and poor people in particular, in other side its concern will be in both of broad fields of social planning, and in community development (Osei-Hwedie, Ntseane, \& Jacques, 2006, p. $81)$.

So, it's important to inform that social work education will therefore, be concerned in equipping social workers to understand the 
main issues of their field, social forces in it, and the current problems of their community to be able find the method through which progress can be achieved on a wide front.

But there are a lot of factors make different, which will discuss in the next part.

\section{1- Social work education in India:}

The social work training began in India started in 1936, and the professional association called the National Accreditation and Assessment Council (NAAC). India offers both generic and specialised course works.

There is thought that Indian social work has functioned in a vacuum of unreality. Because social work education is often ignorant of prevailing conditions and needs of local communities, and its knowledge base has been from the western world rather than the eastern, which is including social work administration - about the various intricate operations of social agencies which are very different in the East.

Widely it is recognised that Indian social work education isn't able to create solutions for social problems of the local community. So India takes a critical look at social work educational system with a view to reforming curriculums, which needs to be match with the economic and social changes.

India is among those developing countries which believe that western social work education is totally unsuited for developing countries, because the process of the intrusion of Western concepts and practices has created for a different culture, and that a micro-systems orientation is irrelevant in the face of macro-developmental needs and challenges. However, most of developing countries today still follow a micro-systems model of education (Ejaz, 1991, p. 382).

In India, there are professional schools of social work which have changed their approach to a more generic one, though the overall trend may be microsystems oriented. That aimed indigenizing social work. In fact, the purpose of the above part is discussing the consequences of using western educational 
system to practice in different culture, and the system of social work education in India is like a model of developing countries.

\section{2- Social Work education in Zimbabwe:}

Closely social work in Zimbabwe is tied to the country's colonial history, its orientation reflecting a wholesale transfer from the British experience. And Zimbabwe like most African countries embraced the curative or remedial approach to solving social problems during its inception, in other words social work in Zimbabwe developed as a response to urban social ills such as crime, prostitution and destitution.

So welfare is largest employer of social workers, but it is mainly suffer from a lot of problems, because of curriculum and institutions of Social work education, need development, which are consequences of a general lack of professional recognition of social workers in Africa, particularly in Zimbabwe. And most people do not believe or understand what social work is, even among some official educators. That is the reason why in Zimbabwe people with no training sociologists and political scientists are employed as "social workers". Rising of Social workers' awareness in Africa is one of necessary requirements (Chitereka, 2009, p. 457).

"All schools of social work should aspire to work towards the development of a core purpose statement or mission statement which reflects aspiration towards equity with regard to the demographic profile of their institution's locality. The core purpose or mission statement should thus incorporate such issues as ethnicity, differential ability and gender representation within the faculty, school, or department, as well as in recruitment and admission procedures for students" (Dziro, 2013, p. 411)

\section{3- Characteristics of Social Work Education in Egypt:}

Social work programs in Arab region are increased at last two decades, through eastern colleges and departments are opened, not only and the programs are upgraded by the Arab educator who had educated in Western universities or Western-educated social workers in Arab universities.

Since 1936, School of Social Work was established in Egypt by two foreign-born social workers and a professor from the American 
University in Cairo when they initiated that idea. Although easterneducated social workers efforts for eighty years of working in Arab region to develop and staff a growing number of social work education programs at the undergraduate and graduate levels (Sloan, Matthews, Bromfield, \& Rotabi, 2017, p. 149)

\section{A- Social work education in The Arabian Gulf region:}

One of the Characteristics of social work education in Arabian Gulf region western social work educators with advanced social work qualifications that are recruited to develop social work programs. That happened in specific period to fill lack of qualified social work educator.

"Currently, in the Arab Gulf region, there are 12 undergraduate social work programs: six in the Kingdom of Saudi Arabia (KSA), three in the UAE, one in Kuwait, one in Qatar, and one in Oman. There are two graduate social work programs in the Gulf: one in KSA and one in the UAE. The faculty in these programs are a combination of citizens and foreign-born social work educators, with many having social work degrees from Western universities. In the UAE, Qatar, and Oman, most faculty, whether citizens or expatriates, were educated in the West." (Sloan, Matthews, Bromfield, \& Rotabi, 2017, p. 176)

The above discussion reflects social workers magnitude in Gulf region, and the general direction and awareness toward social work significant in their community.

\section{b- Social work education in Egypt:}

Currently, Egypt is facing untraditional problems, which rise many social and changes economic conditions, after 25 January revolution, that plus traditional problems such as illiteracy, crime and poverty, as well as emerging challenges such as the gradual increase in population, unemployment, the rising cost of living, and inflation.

Since, 1970s Egypt passed by drastic shifts in social and economic conditions with globalization and the expansion of 
technology were not used by social work educators until now as an opportunity to introduce new initiatives to develop programs.

But the social work curricula in Egypt continued to follow the traditional methods approach which is focused on the results of analysis aged cases work, which are not matching with current shifts, at different work units, as group work and community organization.

If we are comparing between social work history in India and Egypt, there is positive stage in social work education history of Egypt which was creating its own models, and improved the western knowledge to be matching with its culture, but it is not continued, and the failure to assess modern curricula has caused a gap between the quality of social work education measured by the level of knowledge, skills and experience of social work graduates and the need of societal stockholders to acquire qualified social workers who are able to utilize new models of social work practice, and to deal with variant requirements of the current social and economic changes.

Social work curriculums in Egypt now need to update to be able to understand for problems such as illegal migration, refugees, refugees' students, drug addiction, increased marginalization, slum living conditions and children living in the streets. (Soliman \& Abd Elmegied, 2010, p. 53).

The preceding review of social work education in Arab Region is introduction for the main question of current research which is "Are current curriculums convenient to transforms in Arab region? That question is answered by applying the research's tools in forthcoming papers. But next the researcher will discuss some tips of Transforms in Arab Region.

\section{Second: Obstacles of Social work education:}

The preceding review of social work education in developing countries reveals identities a number of problems that have negatively influenced social work education in development countries, which are:-

- Using western social work curriculums, in eastern countries has

Resulted, unqualified social workers, that creates general 
refusing attitude for social work, and there is no societal trust of social workers role, or social work ability of facing problem that are reasons, many social work graduates are unable to find work. So the students of social work programs are not believe that it's not good field to improve their future. But the centralized system of admitting students based on their scores at high-school diploma level rather than according to the college's expectations.

- The over dependency on using of old methods of teaching that rely solely on lecturing; and lack of coordination between schools of social work and each other to improve its curriculums.

The above discussion has discover the challenges face modernization process of social work education in development countries, and describing of the debate between the traditional curriculums, national \& cultural boundaries, so in the following parts the writer will discuss the international experience in teaching social work, While students acquire expertise regarding their own country, domestic social and economic issues are clearly linked to global human rights, social justice.

\section{Third: Description of social transforms in Egypt:}

Egypt is passed hard and complicated social transforms, for example, the armed conflict, the impact of evolutionary technology, sciences development; in the following parts of the present paper will discuss the significant social transforms in Egypt, and describe its consequences, which requires social worker with updating understand different equipment, new qualifications.

\section{1- Refugees' issues:}

As of November 201410.9 million Syrians were displaced within and outside Syria because of the conflict in there, with no signs of abating. Over 3.3 million refugees went to Lebanon, Jordan, Iraq, Turkey, and Egypt, that number is increasing daily. More than 52 percent of the refugee population is children. Lebanon hosts almost 1.15 million, Turkey hosts 1.16 around 
million Syrian refugees, while Jordan hosts 0.62 million. In Iraq, the armed conflict has further compounded the Syrian refugee crisis, in other words over 2.2 million Iraqis displaced within Iraq in the same geographical area as Iraqi IDPs many of the 210,000 Syrian refugees are located, placing a major burden on host communities and services. (Haque, Kjørven, \& Calivis, 2015, p. 317)

The Arab Republic of Egypt ("Egypt") has accepted generously Syrian refugees into Egypt despite the absence of a land border with Syria. As of September 2015, there are 128,019 Syrian asylum-seekers and refugees (including 55,816 children) registered with UNHCR in Egypt and Syria children are hosted in its schools. In comparison to Jordan, Lebanon, Turkey and Iraq they are hosting far smaller numbers of Syrian refugees. There are Syrian refugees in Egypt more than the previous number that according to Government estimates, an equal number or more Syrians are unregistered and living in Egypt. In light of increasing controls on more Syrians are unregistered and living in Egypt.

Egypt also hosts 56,868 asylum seekers and refugees, in addition to hosting Syrian refugees, mostly from Sub-Saharan Africa and Iraq, which account for 29 percent of the 184,887 asylum-seekers and refugees registered with UNHCR in Egypt. (UNHCR, 2017, p. 9)

It is important that state institutions are equipped with qualified human resources and capacities to help refugee and monitoring their needs and their impacts on development in Egypt at large.

\section{2- International social work as new frame of education:}

Currently, the international social work education is perspective emphasized that it is not a new trend. But it profession has long distinguished history of advocating for social changes and enhancing human rights. And international cooperation and collaboration among international institutions of social development and social work emerge necessary to find 
new strategy to achieve their goals. In other side the international cooperation between social workers through, International Conference which is opportunity to exchange knowledge and experience.

Certainly, the deepening interconnected economies, expanding migration patterns, rapidly developing network of global communication, and growing awareness of our interrelatedness has resulted developing in the knowledge of international social work and its theories. Those efforts a lot of researches introduce understand to the world beyond national borders. (Hawkins \& Knox, 2014, p. 36)

A pressing need is to integrate international perspective in to a social work education, which will guide practice in international institution of social development.

The history of international social work is linked to the increase of international social problems which is resulting from international interactions and economic interdependency of our world. For example, profession of social work has been increasingly challenged with the demand for services to assist immigrants and refugees.

The international connections between social work practice, social development, and human empowerment have clearly emerged in the scholarly literature which uses to modernize curriculums.

These discussions continue with further collaborations and new partnerships, and through the researches and paper this special edition of International Social Work to introduce frame work for practice it. That effort emerges the best way to educate social work students toward an analysis of oppressive practices of the international issue as well poverty, shrinking violence, transcend geographical boundaries, and identity locations. (Brown \& Strauss, 2014)

Globally Economic forces constitute a specific factor effecting on social work education, for example the poorer countries have less money to spend on welfare services and the training of social worker, and the values of national political systems which are significant in determining how available money is spent. 
There is relation between political ideology, economic and social work and education, because they have disastrous impacting on social work education, so the system of the education must be organize by international institution to facing the consequences of the economic forces, for example, that review in the model of Zimbabwe, while Vietnam affords an example of positive political support for profession of social work (Hokenstad, 2012, p. 64).

\section{3- the effect of technology development to enhance social work education:}

Australian university is applying online distance education in social work, there are many social-work students have registered and online distance them could be seen to be challenged even further in their preparation for practicum, due to a perception that they are learning practice skills on their own. The evaluation of that method showed that a number struggled to remain engaged, and felt isolated. (Goldingay \& Land, 2014, p. 427)

At Massey University, New Zealand, they are enhancing teaching and learning through applying the same method in social work programs, the result of over the past two years academic evaluation that it offered more relevant resources to field educators with the intention of better supporting them as both educators and learners. There is another feedback, the new system enhance both understand and continue to develop in their critical of educators roles. (Hay \& Dale, 2014)

\section{4- International social work as new frame of education:}

Currently, the international social work education is perspective emphasized that it is not a new trend. But it profession has a long and distinguished history of advocating for social changes and enhancing human rights. And international cooperation and collaboration among international institutions of social development and social work emerge necessary to find new strategy to achieve their goals. In other side the international cooperation 
between social workers through, International Conference which is opportunity to exchange knowledge and experience.

Certainly, the deepening interconnected economies, expanding migration patterns, rapidly developing network of global communication, and growing awareness of our interrelatedness has resulted developing in the knowledge of international social work and its theories. Those efforts a lot of researches introduce understand to the world beyond national borders. (Hawkins \& Knox, 2014, p. 121)

A pressing need is to integrate international perspective in to a social work education, which will guide practice in international institution of social development.

The history of international social work is linked to the increase of international social problems which is resulting from international interactions and economic interdependency of our world. For example, profession of social work has been increasingly challenged with the demand for services to assist immigrants and refugees.

The international connections between social work practice, social development, and human empowerment have clearly emerged in the scholarly literature which uses to modernize curriculums.

These discussions continue with further collaborations and new partnerships, and through the researches and paper this special edition of International Social Work to introduce frame work for practice it. That effort emerges the best way to educate social work students toward an analysis of oppressive practices of the international issue as well poverty, shrinking violence, transcend geographical boundaries, and identity locations. (Brown \& Strauss, 2014, p. 259)

Globally Economic forces constitute a specific factor effecting on social work education, for example the poorer countries have less money to spend on welfare services and the training of social worker, and the values of national political systems which are significant in determining how available money is spent.

There is relation between political ideology, economic and social work and education, because they have disastrous impacting on 
social work education, so the system of the education must be organize by international institution to facing the consequences of the economic forces, for example, that review in the model of Zimbabwe, while Vietnam affords an example of positive political support for profession of social work (Hokenstad, 2012, p. 283).

\section{Methodology}

The population in this study consists of social work students in Fayoum University, because Fayoum is poorest governorate according of last human development reports 2010 (UNDP, National Planning institution, 2015), although its economic circumcise, it is including refugees and their children in its schools, so social workers in those schools deal and face a new clients with new needs and problems, without any previous experiences with them.

A random sample of the fourth year students in faculty of social work- Fayoum University 2019/2020 was selected, by terms of Richard Jeager's equation which is :

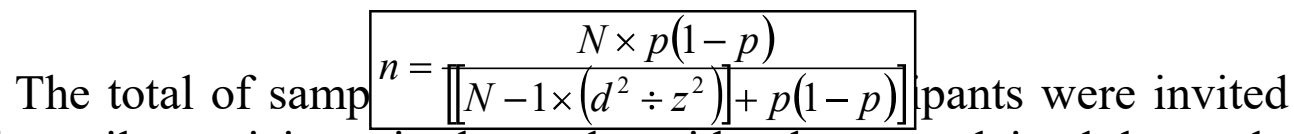
to voluntarily participate in the study, with a letter explained the study procedures and assuring respondents about confidentiality of identity and information provided.

The researchers received 251surveys, which reflected a response rate of 91.6 percent.

In other side the study instrument was based on the available literature on transforms in Arab region and the ideas generated from discussion of the topic following a presentation on reforming and redesigning social work education in Arab region.

The instrument is consisted of part aimed to gather student suggestions about developing of social work curriculum and three subscales:-

1- Discretion of the student realization of Social transforms in Egypt.

2- Student perception of the effectiveness of Social transforms in Egypt. 
3- Views of the social work curriculum: the ideas of social work student on the current status of the curriculum if it is convenient to equip them for dealing, facing and combating social problem which is consequences of Social transforms in Egypt.

The current instrument was assessed for the validity of it. That process included content and constructs validity, as ten Egyptian professors are members in faculty of social work - Fayoum University -Umm Al-Qura University, they reviewed and discussed the content of the instrument in relation to existing initiatives involving the restructuring of the curricula.

In terms of construct validity of instrument, the validity test was done to get valid three variables of instrument so reliability test is done by using Cronbach's alpha technique. Each variable tested in this study after being tested for validity and reliability provides valid and reliable results, as below:

Table -1 Validity Test

\begin{tabular}{|l|l|l|l|}
\hline Variable & $\begin{array}{l}\text { No. of } \\
\text { Items }\end{array}$ & $\begin{array}{l}\text { Correlation } \\
\text { Value }\end{array}$ & Status \\
\hline $\begin{array}{l}\text { student realization of Social } \\
\text { Transforms in Egypt }\end{array}$ & $\mathbf{1 0}$ & $\mathbf{0 . 8 9}$ & Valid \\
\hline $\begin{array}{l}\text { Student perception of the } \\
\text { effectiveness of Social Transforms in } \\
\text { Egypt. }\end{array}$ & $\mathbf{1 1}$ & $\mathbf{0 . 9 0}$ & Valid \\
\hline $\begin{array}{l}\text { Student's Views about convenience } \\
\text { of current social work curriculums to } \\
\text { qualify them }\end{array}$ & $\mathbf{1 0}$ & $\mathbf{0 . 8 9}$ & Valid \\
\hline
\end{tabular}

Table -2 Reliability Test

\begin{tabular}{|lll|l|l|}
\hline Variable & & $\begin{array}{l}\text { No. of } \\
\text { Items }\end{array}$ & $\begin{array}{l}\text { Correlation } \\
\text { Value }\end{array}$ & Status \\
\hline $\begin{array}{l}\text { student realization of Social } \\
\text { Transforms in Egypt }\end{array}$ & $\mathbf{1 0}$ & $\mathbf{0 . 8 8}$ & Very reliable \\
\hline $\begin{array}{l}\text { Student perception of the } \\
\text { effectiveness of } \\
\text { Transforms in Egypt. }\end{array}$ & Social & $\mathbf{1 1}$ & $\mathbf{0 . 9 2}$ & Very reliable \\
\hline \begin{tabular}{l} 
Student's Views \\
\hline
\end{tabular} & about & $\mathbf{1 0}$ & $\mathbf{0 . 8 9}$ & Very reliable \\
\hline
\end{tabular}




\begin{tabular}{|l|l|l|l|}
\hline Variable & $\begin{array}{l}\text { No. of } \\
\text { Items }\end{array}$ & $\begin{array}{l}\text { Correlation } \\
\text { Value }\end{array}$ & Status \\
\hline $\begin{array}{l}\text { convenience of current social } \\
\text { work curriculums to qualify } \\
\text { them }\end{array}$ & & & \\
\hline
\end{tabular}

The validity of the variable ranged from 0.89 to 0.90 with an overall validity efficiency of the entire scale at .89 . Validity reflects the internal consistency of the subscales, ranging from 0.89 to 0.90 , with an overall reliability efficiency of the whole scale of .78 .

The reliability of the variable ranged from .88 to 0.92 with an overall reliability co efficiency of the entire scale at 0.88 . Reliability reflects the internal consistency of the subscales, ranging from 0.88 to 0.92 , with an overall reliability co efficiency of the whole scale of 0.88 .

Results and Discussions:

Descriptive analyses of the study sample show the specifications of participants which are shown through the table below:

Table -3 identify specifications of study sample

\begin{tabular}{|l|l|l|l|}
\hline Variable & Percent & Frequency \\
\hline \multirow{2}{*}{ gender } & Male & 83 & 33.1 \\
\cline { 2 - 4 } & Female & 168 & 66.9 \\
\hline \multirow{2}{*}{$\begin{array}{l}\text { The domain of } \\
\text { their training in } \\
\text { college }\end{array}$} & education domain & 94 & 37.5 \\
\cline { 2 - 4 } & NGOs domain & 75 & 29.9 \\
\cline { 2 - 4 } & Health domain & 82 & 32.7 \\
\hline
\end{tabular}

Variations of the answers refer to participants divided to 168 male $(33.1 \%)$ and 83 are female (66.9\%). The distribution of the participants by the domain of the training in their college is 37.5 percent for who their domain of training is education domain, 32.7 percent for who their domain of training is Health domain, and 29.9 percent for who their domain of training is NGOs domain.

Table -4 identify level of social work student realization

\begin{tabular}{|c|c|c|c|}
\hline Variable & $\begin{array}{l}\text { No. of } \\
\text { Items }\end{array}$ & mean & $\begin{array}{l}\text { Std. } \\
\text { deviation }\end{array}$ \\
\hline $\begin{array}{l}\text { student realization of Social } \\
\text { transforms in Egypt }\end{array}$ & 10 & 9.7 & 3.5 \\
\hline $\begin{array}{l}\text { Student perception of the } \\
\text { effectiveness of Social }\end{array}$ & 11 & 7.4 & 4.1 \\
\hline
\end{tabular}


مجلة كلية الخدمة الاجتماعية للار اسات و البحوث الاجتماعية - جامعة الك

\begin{tabular}{|l|l|l|l|}
\hline Variable & $\begin{array}{l}\text { No. of } \\
\text { Items }\end{array}$ & mean & $\begin{array}{l}\text { Std. } \\
\text { deviation }\end{array}$ \\
\hline $\begin{array}{l}\text { transforms in Egypt. } \\
\begin{array}{l}\text { Student's Views about } \\
\text { convenience of current social } \\
\text { work curriculums to qualify } \\
\text { them }\end{array}\end{array}$ & $\mathbf{1 0}$ & 11.2 & 2.1 \\
\hline
\end{tabular}

The results of the study provide evidence of factors that relate to the convenience current social work curriculum to equip social workers able to deal with the consequences of Social transforms in Egypt. In terms of descriptive method, which refer that social work curriculum wasn't sufficient enough to equip social workers able to deal with the consequences Social transforms in Egypt, that result was shown in the previous table, particularly what mean value of students responses of variable2 " Student perception of the effectiveness of Social transforms in Egypt " which was (7.4) and Std. deviation value which was (4.1) reflect their persuasion bout social work curriculums do not include current Arab region issues and their consequences.

The similar result for mean value of variablel "student realization of Social transforms in Egypt" which was (9.7), Std. deviation value was (3.5), which reflect social work students believe that curriculums modernizing should happen.

And the result of variable3 "student's views of about convenience of current social work curriculums to qualify them" was not different, because its value mean was (11.2), and Std. deviation value was (2.1).

The results of the study provide evidence of factors that it's urgent need to modernize social work education. Because of speed of Social transforms in Egypt and its consequences became unexpected and various.

\section{Conclusion:}

This research has taken Egypt as an example; one of the main reasons was its long history and role in spreading social work education in the Middle East. In general, Egypt as one countries of Arab region is 
facing complicated and urgent problems require creative interventions from human sciences, especially social work because it is significant element in the majority of social institution in any society not just in Egypt.

In other side, social work education became an international topic; an examination of challenges for social work modernization may be relevant to social work educators across the world. Social work education in Egypt faces challenges which may detract from the profession's abilities and its relevance to society's efforts to address its problems.

An increased emphasis on the Obstacles of Social work education in developing countries, which depends upon many factors such as quality of curriculum, applying the western knowledge in eastern countries, institutional structure of the institution of social work profession and education, competence of students, quality of the teachers recruited and promoted, their roles and responsibilities and the skill, type of knowledge component developed and applied in the teaching-learning processes, and both of the Accreditation processes of social work programs, the permission of profession practice, which are not available in that countries.

Certainly, there is pressing need which is incorporate the societal needs in its curriculum, This requirement is vital for the social work profession, which directly deals with the human issues, and in generally any professional branch of education dealing with the needs of the society.

Besides this, the social work education has to updating its knowledge base contextually to make it indigenous, because it is a dynamic profession, and has to keep pace with the changing social conditions.

In other side, there are current trends occurring across the world provide very compelling evidence of requirement for new approaches to social work education and practice internationally.

These requirements include pressing current global crises which is consequence of eastern war, and it is result growth of political and economic refugees in the world, terrorism, dramatic rise in global poverty, disparity, and continued issues of extreme famine across the 
globe; and human rights violations such as the growing world problem human enslavement; global warming; global pandemics; and problems of homelessness combined with increased unemployment and underemployment.

Many of the most challenging domestic social problems need corporation between the international institution of social work to update its knowledge and create new method, to enhance social workers roles in facing those international challenges. 


\section{References:}

1- Austin, M. J. (2014). Educating Social Work Students About Social. In B. G. Lehning, Social Justice and Social Work: Rediscovering a Core Value of the Profession (pp. 339-356). Thousand Oaks: SAGE Publications.

2- Brown, M., \& Strauss, H. (2014). Educating for internationalizing social work practices. International Social Work, 197-200.

3- Carrillo, G. D. (2019). The U.S. Globalization of Social Work Education:The Impact and Implications on Practice in aDeveloping Country. Minnesota : University of St. Thomas, Minnesota.

4- Chitereka, C. (2009). Social Work Practice in a Developing Continent:The Case of Africa . Advances in Social Work, 144156.

5- Dziro, C. (2013). Trends in social work education and training: The case of Zimbabwe. International Journal of Development and Sustainability, 1423-1435.

6- Ejaz, F. K. (1991). Social work education in India: perceptions of social workers in Bombay. International Social Work, 299311.

7- Faruque, C. J., \& Ahmmed, F. (2013). Development of Social Work Education and Practice in an Era of International Collaboration and Cooperation. International Social Issues, 6170.

8- Goldingay, S., \& Land, C. (2014). Emotion: The 'e' in engagement in online distance education in social work. Journal of Open, Flexible, and Distance Learning, 58-72.

9- Haque, Y., Kjørven, O., \& Calivis, M. (2015). Humanitarian Action for Children. New York: UNICEF.

10- Hawkins, C. A., \& Knox, K. (2014). Educating for international social work: Human rights leadership. International Social Work, 248-257. 
11- Hay, K., \& Dale, M. (2014). Using e-technology to enhance social work field education. Journal of Cooperative Education, 119-128.

12- Health\&Care-Professions-Council. (2016). Social Work Education in England. London: the Health and Care Professions Council (HCPC).

13- Hokenstad, T. (2012). Social Work Education: The International Dimension. In T. H. Karen Lyons, The SAGE Handbook of International Social Work (pp. 163-178). London: SAGE Publications.

14- Hugman, R., Durst, D., \& Loan, L. (2009). Developing Social Work in Vietnam: Issues in Professional Education. Social Work Education, 177-789.

15- Morgaine, K. (2014). conceptualizing social justice in social work: are social workers too bogged down in the trees. Journal of social justice, 2164-7100.

16- Nadir, U., \& Aktan, M. C. (2016). SOCIAL JUSTICE, EDUCATION AND SCHOOL SOCIAL WORK IN. Journal of Baskent University, 217-221.

17- Napier, L., \& George, J. (2001). Changing social work education in Australia. SOCIAL WORK EDUCATION, 75-87.

18- Osei-Hwedie, K., Ntseane, D., \& Jacques, G. (2006). Searching for Appropriateness in Social Work Education in Botswana: The Process of Developing a Master inSocial Work (MSW) Programme in a'Developing' Country. Social Work Education, 569-590.

19- Ring, C. (2014). Social Work Training or Social Work Education? An Approach to Curriculum Design. Social Work Education, 1101-1108.

20- Sheehan, R. (2016). Forensic Social Work: Implementing Specialist Social Work Education. Journal of Social Work, 726741.

21- $\quad$ Skills.for.Care. (2015). Social work education in England 2009 - 2014. West Gate: Skills for Care for the Department of Health. 
22- $\quad$ Sloan, L. M., Matthews, J., Bromfield, N., \& Rotabi, K. (2017). Social work education in the Arabian Gulf: Challenges and opportunities. JOURNAL OF RELIGION \& SPIRITUALITY IN SOCIAL WORK: SOCIAL THOUGHT, 199-214.

23- Soliman, H. H., \& Abd Elmegied, H. S. (2010). The challenges of modernization of social work education in developing countries: The case of Egypt. international Social work, 101-114.

24- UNDP, National Planning institution. (2015). Local human development report for governorate- Fayoum 2015. Cairo: UNDP.

25- $\quad$ UNHCR. (2017). EGYPT Regional Refugee \& Resilience Plan 2016-2017. Cairo: UNHCR. 
مجلة كلية الخدمة الاجتماعية للدر اسات و البحوث الاجتماعية ـ جامعة الكيوم 